\title{
Fatal cardiovascular risk in Poland as determined via Internet
}

\author{
Bartosz Trzeciak ${ }^{1}$, Piotr Gutknecht ${ }^{1}$, Andrzej Molisz ${ }^{1}$, Janusz Siebert ${ }^{1}$ \\ ${ }^{1}$ Medical Unversity of Gdańsk, Poland
}

Trzeciak B, Gutknecht P, Molisz A, Siebert J. Fatal cardiovascular risk in Poland as determined via Internet. Ann Agric Environ Med. 2017; 24(2): 176-180. doi: 10.5604/12321966.1235161

\begin{abstract}
Introduction. Web information systems can serve as a diagnostic tool for Internet users and to support the epidemiological work of doctors and health care providers. As part of this work, a system for detecting and calculating cardiovascular risk has been created.

Objectives. 1) Application of web-based risk assessment of cardiovascular death; 2) an attempt to evaluate the distribution of selected risk factors among the population of Polish Internet users; 3 ) implementation of the epidemiological imaging system of cardiovascular risk factors.

Materials and method. The 'Ryzyko' programme (www.ryzyko.gumed.edu.pl.) available on the Internet. To assess cardiovascular death risk in a ten year period the algorithm of the SCORE project was used. 28,320 solutions of the algorithm have been registered.

Results. Over 28,000 webpage visitors entered the required data and received the outcome. More than $71 \%$ of Internauts who entered the data received the recommendation for medical control. The result of the programme is a graphic presentation of the distribution of the calculated risk of death, based on previously gathered information given by the Internauts in particular provinces in Poland.

Conclusion. Automatic monitoring of the incidence of cardiovascular risk factors in Poland provides information for epidemiological studies. The system meets the characteristics of diagnostic programmes that can assist epidemiologicbased and therapeutic decisions.
\end{abstract}

\section{Key words}

cardiovascular risk factors, Internet in healthcare, risk, 'Ryzyko' programme, SCORE

\section{INTRODUCTION}

Despite implementation of large prevention programmes in Poland and Europe, diseases of the cardiovascular system still remain the primary cause of death [1]. Cardiovascular disease mortality (ICD10: I00-I99 - ICD10: International Classification of Diseases ICD-10[2]) in Poland in 2008 reached $45.6 \%$ [3]. The increase in mortality was observed in the early 1990s although a downward trend in the cardiovascular disease mortality curve continues until today. However, the number of deaths due to cardiovascular diseases in Poland is still higher than in most European countries [4].

Primary and secondary cardiovascular disease prevention begins with changes in lifestyle. The first step is to eliminate smoking, change to a healthy diet, increase physical activity, and learn how to cope with stress. Further risk factors to be modified include obesity (especially abdominal obesity), hypertension, high LDL cholesterol and triglycerides concentration and metabolic syndrome components $[5,6]$.

Prophylactic routine tests are often not performed at the required time intervals, or are not carried out at all. On the one hand, a bad socio-economic situation and often above normal working time cause excessive fatigue and increasing stress levels, while on the other hand, lack of time to address non-work activities, including medical appointments, are predominant factors.

Address for correspondence: Bartosz Trzeciak, Medical Unversity of Gdańsk, Poland E-mail: bartolomi@gumed.edu.pl

Received: 17 January 2013; accepted: 9 Ocrober 2014; first published on February 2017
Excess working time results in an increased number of cardiac events independent of other risk factors for cardiovascular disease [7]. Numerous complaints over the years may be underestimated or 'waited-out' by the use of over-the-counter drugs or home remedies.

High-risk individuals may not be aware of the disease, and the situation in the Polish healthcare system is not conducive to providing adequate preventive care in the population. The development of information-technology and still wider public access to the Internet is available to a large part of society and raises awareness about the possible threat of disease and its consequences.

Education of the public concerning the risk factors for cardiovascular disease and assessment of individual cardiovascular risk becomes the primary goal of prevention from cardiovascular disease. Various techniques are used for information and education, including the ever more widely available Internet. To achieve this goal, a communal system for automatic assessment of cardiovascular risk seems to be very useful. This system gives an opportunity for people who use medical portals and receive information in this way; many of them will contact a doctor to verify the information obtained. Only then can appropriate action be taken by medical personnel. Educational programmes have the opportunity to reach the right audience and thereby promote the prevention of primary and secondary prevention. Classic epidemiological studies are cost-intensive, time-consuming and require large amounts of personal activities. The Internet system that requires virtually no funding appears to be ideal for gathering epidemiological data. 


\section{OBJECTIVES}

1. Application of web-based risk assessment of cardiovascular death;

2. An attempt to evaluate the distribution of selected risk factors among the population of Polish Internet users;

3. Implementation of the epidemiological imaging system of cardiovascular risk factors.

\section{MATERIALS AND METHOD}

The 'Ryzyko' programme is available on the website at: www. ryzyko.amg.gda.pl. To assess cardiovascular death risk in a 10 year period, the algorithm of the SCORE project was used for hi-risk countries, including Poland, as published in the European Heart Journal (2003) 24, 987-1003 [8]. Since $2004,28,532$ solutions of the algorithm have been registered and the data collected was analysed in 2012. The following parameters were collected: age, gender, systolic blood pressure, total cholesterol concentration, and whether or not the user smoked. The Internet 'Ryzyko' users were also asked to input their ZIP code in order to locate the distribution of the risk factors in further analysis, and the presence of diabetes mellitus and cardiovascular disease, for generating recommendations to visit a doctor and the necessary lifestyle changes. Each solution of the algorithm was considered as if it were another webpage visitor. Each Internet user of the programme was able to see the graphic and numerical outcome after entering his/her personal data, as required by the programme. If the input data extended beyond the limits recommended by the European Society of Cardiology and Prevention [9] and /or the calculated death risk in the 10 year period was greater than or equal to $5 \%$, a visit to a doctor was recommended. For those aged under 40 , due to the very low risk calculated by the algorithm, even when considerably exceeding the recommendation values, the age was approximated to 60 years and the risk was calculated for such values. The result of the programme is a graphic presentation of the distribution of the calculated risk of death, based on previously gathered information given by the Internauts, in particular provinces in Poland.

Ranges of input values in the 'Ryzyko' programme:

- Age [years] 18-39/40-65/66-99;

- SBP [mmHg] 80-250.

Internet users were divided by age group:

1) young people aged 18-39 years - low-risk group;

2) middle-aged people: $40-65$ years of age - group at high risk of cardiovascular disease;

3) the elderly: 66-99 years - very high-risk group; and by gender, declared coronary heart disease, diabetes, cigarette smoking, hypertension, and prevalence of hypercholesterolaemia. Target values and standards of blood pressure and cholesterol levels were adopted from ESH-ESC.

Internet users smoking at least 7 cigarettes a week were assumed to be cigarette smokers. Internet users who declared systolic blood pressure exceeding or equal to $140 \mathrm{~mm} \mathrm{Hg}$ were included as hypertensive individuals.

Internet users who declared the level of total cholesterol concentration equal to or greater than $5 \mathrm{mmol} / \mathrm{l}$ were included as highcholesterolemic individuals.
To illustrate the scale of the calculated risk, the following risk bands were determined:

- negligible $<1 \%$;

- very low $\geq 1$ and $<2 \%$;

- low $\geq 2$ and $<3 \%$;

- average of $\geq 3$ and $<5 \%$;

- high $\geq 5$ and $<10 \%$;

- very high $\geq 10$ and $<15 \%$;

- extremely high $>25 \%$.

All epidemiological data and the results were gathered on a MySql base on the server of the Medical University of Gdansk, and the results presented as a percentage of the total population; numbers were rounded to one decimal place. Elements of descriptive statistics were used in this work. The rationale for this approach was an attempt to determine whether the Internet is a useful tool for achieving the objectives of the study. However, the statistical results obtained which achieved significance in the analysis could be vitiated by errors arising from the open character of the tool. To illustrate the potential capabilities of the programme, selected statistical analysis were performed: Shapiro-Wilk, Kolmogorov-Lilliefors Smirnov and U-Mann-Whitney tests were used. In all cases, distributions other than normal were obtained.

\section{RESULTS}

The automatic webpage visitor counter on the main page of the 'Ryzyko' programme showed 75,160 visits, of whom $28,320(37.7 \%)$ entered data and received the resolved algorithm output.

Characteristics of the general population (Tab. 1): $64.2 \%$ $(n=18,195)$ of the general population were Internet users in the age group $40-65$ years.

Table 1. Characteristics of the general population $(\mathrm{N}=28320)$

\begin{tabular}{|c|c|c|c|c|}
\hline General & $\mathrm{F}+\mathrm{M}$ & M & $\mathrm{F}$ & $\mathrm{p}$ \\
\hline $\mathrm{N}$ & 28,320 & $15,532(54.8 \%)$ & $12,788(45.2 \%)$ & \\
\hline Mean age $(X \pm S D)$ [years] & $45.0 \pm 13.4$ & $45.4 \pm 13.7$ & $44.6 \pm 13.0$ & 0.041 \\
\hline $\begin{array}{c}\text { Mean total cholesterol } \\
\text { concentration }(\mathrm{X} \pm \mathrm{SD}) \\
{[\mathrm{mmol} / \mathrm{l}]}\end{array}$ & $5.53 \pm 1.96$ & $5.53 \pm 2.05$ & $5.53 \pm 1.85$ & 0.041 \\
\hline \multicolumn{5}{|l|}{$\begin{array}{l}\text { Mean total cholesterol } \\
\text { concentration in age- } \\
\text { groups }[\mathrm{mmol} / \mathrm{l}]\end{array}$} \\
\hline $18-39$ & $4.86 \pm 2.37$ & $4.92 \pm 2.46$ & $4.80 \pm 2.26$ & 0,046 \\
\hline $40-65$ & $5.83 \pm 1.58$ & $5.82 \pm 1.70$ & $5.85 \pm 1.42$ & 0,032 \\
\hline $66-99$ & $5.71 \pm 2.16$ & $5.60 \pm 2.37$ & $5.87 \pm 1.80$ & 0,000 \\
\hline $\begin{array}{c}\text { Mean arterial blood } \\
\text { pressure }(\mathrm{X} \pm \mathrm{SD})[\mathrm{mmHg}]\end{array}$ & $131.7 \pm 20.8$ & $134.5 \pm 20.0$ & $128.4 \pm 21.1$ & 0,000 \\
\hline \multicolumn{5}{|l|}{$\begin{array}{c}\text { Mean arterial blood } \\
\text { pressure in age-groups } \\
{[\mathrm{mmHg}]}\end{array}$} \\
\hline $18-39$ & $124.8 \pm 18.0$ & $129.1 \pm 17.5$ & $119.6 \pm 17.3$ & 0,046 \\
\hline $40-65$ & $134.2 \pm 20.8$ & $136.5 \pm 20.2$ & $131.5 \pm 21.1$ & 0,032 \\
\hline $66-99$ & $142.7 \pm 23.2$ & $141.5 \pm 24.4$ & $144.4 \pm 21.2$ & 0,000 \\
\hline
\end{tabular}

$\mathrm{F}$ - Female Internet users

M - Male Internet Users 
Table 2. Characteristics of DM population $(\mathrm{N}=1846)$

\begin{tabular}{|c|c|c|c|c|}
\hline DM & $\mathrm{F}+\mathrm{M}$ & M & $\mathrm{F}$ & $\mathrm{p}$ \\
\hline $\mathrm{N}$ & 1846 & $1252(67.8 \%)$ & $594(32.2 \%)$ & \\
\hline Mean age $(X \pm S D)$ [years] & $54.1 \pm 14.6$ & $54.0 \pm 14.7$ & $54.2 \pm 14.5$ & 0,1 \\
\hline $\begin{array}{c}\text { Mean total cholesterol } \\
\text { concentration }(\mathrm{X} \pm \mathrm{SD})[\mathrm{mmol} / \mathrm{l}]\end{array}$ & $6.14 \pm 2.78$ & $6.22 \pm 3.03$ & $5.97 \pm 2.17$ & 0,103 \\
\hline \multicolumn{5}{|c|}{ Mean total cholesterol concentration in age-groups [mmol/l] } \\
\hline $18-39$ & $6.27 \pm 4.30$ & $6.61 \pm 4.63$ & $5.51 \pm 3.34$ & 0,137 \\
\hline $40-65$ & $6.01 \pm 2.11$ & $6.02 \pm 2.32$ & $6.01 \pm 1.56$ & 0,068 \\
\hline $66-99$ & $6.64 \pm 3.78$ & $6.89 \pm 4.06$ & $6.18 \pm 3.14$ & 0,239 \\
\hline $\begin{array}{l}\text { Mean arterial blood pressure } \\
\qquad(\mathrm{X} \pm \mathrm{SD})[\mathrm{mmHg}]\end{array}$ & $143.9 \pm 24.5$ & $145.0 \pm 24.4$ & $141.8 \pm 24.7$ & 0,103 \\
\hline \multicolumn{5}{|c|}{ Mean arterial blood pressure in age-groups [ $\mathrm{mmHg}]$} \\
\hline $18-39$ & $137.3 \pm 26.9$ & $142.0 \pm 27.1$ & $127.1 \pm 23.5$ & 0,137 \\
\hline $40-65$ & $142.9 \pm 22.5$ & $143.4 \pm 22.0$ & $141.8 \pm 23.5$ & 0,068 \\
\hline $66-99$ & $154.2 \pm 27.8$ & $154.8 \pm 29.6$ & $153.1 \pm 24.0$ & 0,239 \\
\hline
\end{tabular}

F- Female Internet users

M - Male Internet Users

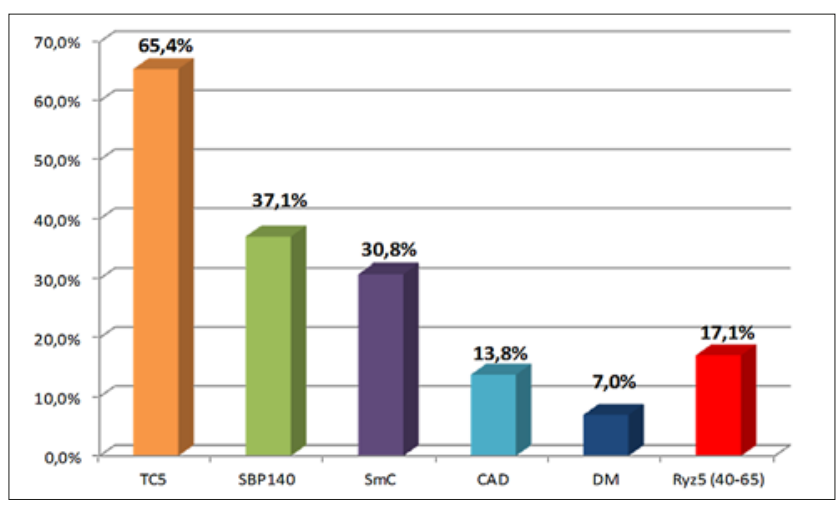

Figure 1. Percentage of Internet users with risk factors of cardiovascular diseases and high risk of death within the period of 10 years in the general population ( $\mathrm{N}$ $=28,320$ ) of the 'Ryzyko' programme

TC5 - No. of high cholesterolaemic Internet users (total cholesterol concentration TC5 - No. of high cholesterolaemic Internet users (total cholesterol
$\geq 5 \mathrm{mmol} / \mathrm{l})$, expressed as a percentage of the general population.

SBP140 - No. of Internet users with hypertension $(\geq 140 \mathrm{mmHg})$, expressed as a percentage of the general population.

SmC - No. of Internet users who declared smoking ( $\geq 7$ cigarettes/week), expressed as a percentage of the general population.

CAD - number of Internet users who declared coronary artery disease, expressed as a percentage of the general population.

DM - number of Internet users who declared diabetes mellitus, expressed as a percentage of the general population.

Figure 5. (40-65) - No. of Internet users with calculated high risk $(\geq 5)$ in the age group 40-65 years, expressed as a percentage of the general population.

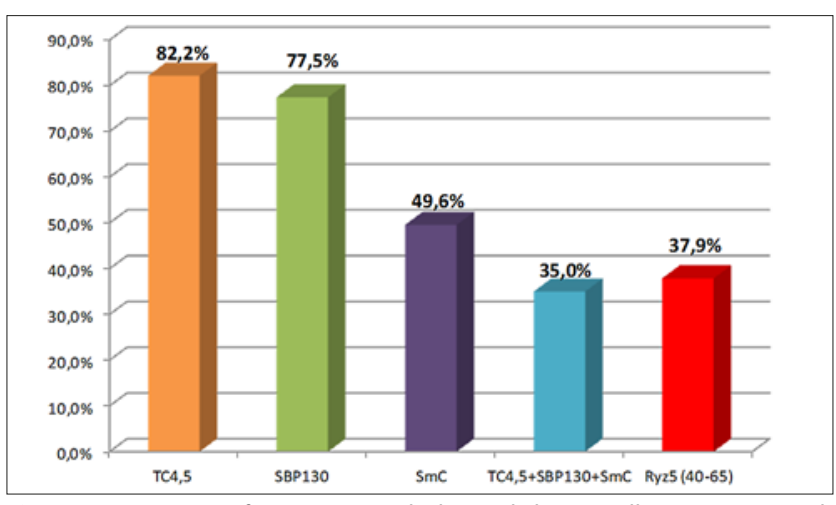

Figure 2. Percentage of Internet users declaring diabetes mellitus $(\mathrm{N}=1,846)$ with additional elements of risk of cardiovascular diseases with a high risk of death within the period of 10 years

TC4,5 - No. of high cholesterolaemic Internet users (total cholesterol $\geq 4.5 \mathrm{mmol} / \mathrm{l}$ ), expressed as a percentage of the general DM population.

SBP130 - No. of Internet users with blood pressure $\geq 130 \mathrm{mmHg}$, expressed as a

percentage of the general DM population.

SmC - No. of Internet users who declared smoking ( $\geq 7$ cigarettes/week), expressed as a percentage of the general DM population.
The highest average value of the calculated risk of death (in excess of 5\%) in the age-group of 40-65 years was recorded in the Kujawsko-Pomorskie and Podlaskie provines (Fig. 3); lowest average value (below 2\%) in Podkarpackie province.

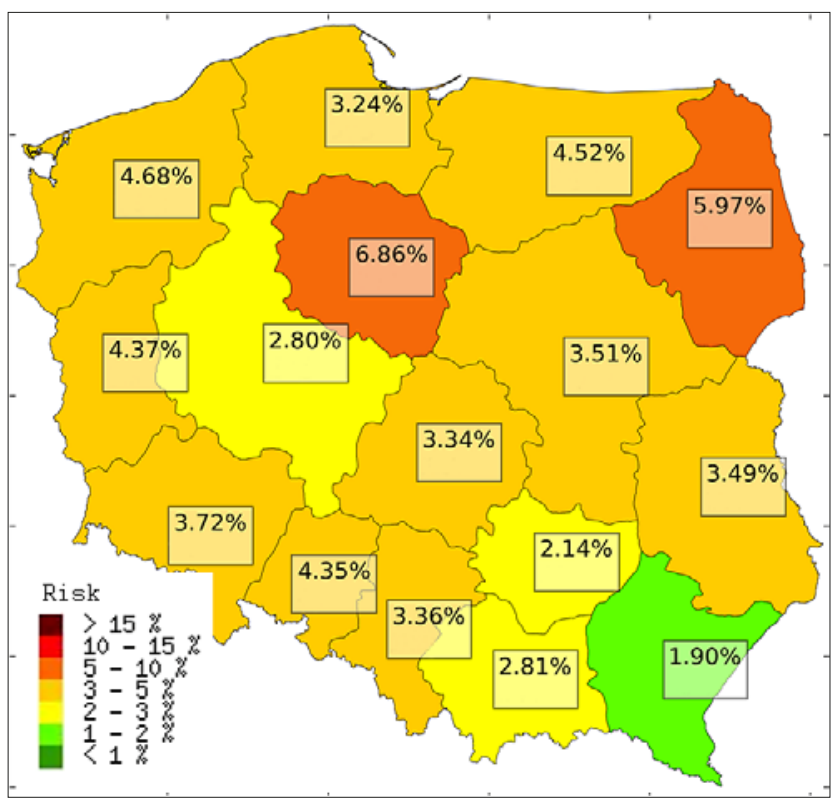

Figure 3. Average risk of death due to cardiovascular diseases among Internet users in Poland in the age-group 40-65 years.

\section{DISCUSSION}

The Polish government is devoting significant amounts of money for development of the Internet in Poland. In 2013, 99\% of eastern Polish territory should be covered with access to the broadband network [10]. The Internet seems to be the ideal agent for health promotion, secondary prevention and even more important - primary prevention. The 'Ryzyko' programme meets the needs of modern society, operates practically free of charge, and reaches a wide audience. Anyone - after entering the required data - can obtain a result about the calculated risk of death from cardiovascular disease in a 10 year period. The graphic presentation of the result as a comparison with the example of the calculated risk for the same age, but without other risk factors, facilitates understanding of the CVD risk and shows the goal for introducing changes in lifestyle. Automatically generated recommendations additionally indicate the direction of necessary changes in habits and customs. A person with modifiable risk factors receives the recommendation to consult a doctor. Changing the values of entry data during the next visit on the website allows observation of the impact of particular risk factors on the calculated risk of death.

Increasing a patient's knowledge about the disease and the possibility of reducing the risk of cardiovascular disease appears to be crucial in achieving the primary and secondary prevention goal. In Canada, there has been achieved an effectiveness of antihypertensive therapy (almost 66\%) which is unprecedented worldwide $[11,12,13,14]$. This may be due to the high awareness of patients gained through training and good contact between patient and doctor. Canadian Recommendations for hypertension treatment does not practically differ from those in Europe [5] or America [15]. 
Analysis of the findings from the 'Ryzyko' database highly correlate in several respects with the results of large epidemiological studies performed in the traditional way in Poland in recent years. In a study on a small Pomeranian rural population (469 people), knowledge about their own blood pressure was high (almost $75 \%$ of respondents knew the value of their blood pressure), but despite this knowledge, $51 \%$ of the subjects had elevated blood pressure $(\geq 140 / 90$ $\mathrm{mmHg})[16]$.

The results of the 'Ryzyko' programme indicate that the study met with great interest among Internet users. Since the program was initiated in 2004 , there have been 75,160 entries on the main page. Almost $38 \%$ of the visitors $(28,320)$ input data to assess individual cardiovascular death risk in a 10 year period.

In the 'Ryzyko' database, over $64 \%$ of the Internet users belonged to the age group of 40-65 years, and approximately $31 \%$ to the age group $18-39$ years. Given the fact that in Poland the Internet is used mainly by young people[17], it can be assumed that a large number of the Internet users were in the middle-age group, who solved the algorithm to obtain a result due to the need for information about the state of their health because of the first appearance of symptoms of the disease, or had already developed cardiovascular disease. The majority of 'Ryzyko' users were male (55\% male vs. $45 \%$ female), which corresponds with the Internet users in Poland and Europe[18].

In the 'Lipidogram 2003' pilot study [19, 20], 72\% of primary care patients had elevated levels of cholesterol: 69\% of the hypercholestrolaemic patients were female and $72 \%$ were male. In the 'SPES' study [21], hypercholesterolemia was diagnosed in $55.8 \%$ of individuals with a negative history of ischemic heart disease. In the 'WOBASZ' [22] study (more than 16,000 people examined), more than $65 \%$ of the participants were diagnosed with hypercholesterolemia (males - 67\%; females - 64\%). In the 'Ryzyko' programme among the general population, the Internauts reported hypercholesterolaemia (total cholesterol level of more than or equal to $5 \mathrm{mmol} / \mathrm{l}$ ) in $65.4 \%$ of the 'Rryzyko' webpage visitors (females - 66.8\%; males - 64.4\%).

Cholesterol concentration in the 'Lipidogram 2004' study amounted in women to $227 \mathrm{mg} \%(5.9 \mathrm{mmol} / \mathrm{l})$ and in men $220 \mathrm{mg} \%$ (5.72 $\mathrm{mmol} / \mathrm{l})$. In the 'Ryzyko' database, the total cholesterol concentration in blood in the whole group ogf Internauts was lower and amounted $5.5 \mathrm{mmol} / \mathrm{l}$. However, given the mean age of the patients in the 'Lipidogram 2004' study, averaging $55.1 \pm 10.6$ years (min 30 , max 98 years), the more appropriate age group to compare is the group of 40-65 years from 'Ryzyko' programme in which the average age was $50.5 \pm 6.6$ years. In this group, the average total cholesterol concentration approached the result of the 'Lipidogram 2004' study - $5.83 \pm 1.58 \mathrm{mmol} / \mathrm{l}$ (M: 5.82 $\mathrm{mmol} / \mathrm{l} \mathrm{F}: 5.85 \mathrm{mmol} / \mathrm{l})$.

In the 'NATPOL PLUS' [23] study, hypertension occurred in $29 \%$ of respondents. This percentage was lower than in the 'Pol-Monica' study[24, 25] (41\% and 44\%) and 'NATPOL II' [26] study (44\%). In the 'WOBASZ' study, 32.9\% of females and $42.1 \%$ of males (average $36 \%$ ) had elevated blood pressure. Mean arterial pressure was $137.6 \mathrm{mmHg}$ in men and 129.7 $\mathrm{mmHg}$ among women. In the 'Ryzyko' programme, mean arterial pressure was $131.7 \mathrm{mmHg}$ (females - $128.4 \mathrm{mmHg}$; males - $134.5 \mathrm{mmHg}$ ), and in the $40-65$ years age group $134.2 \mathrm{mmHg}$. The incidence of hypertension in the general population was $37.1 \%$ of Internet users (females - 31.8\%; mal;es - 41.4\%).

Analysing the trend incidence of smoking during the last 30 years in the published studies carried out on Poland: in the 1980 s, $34 \%$ of women and $59 \%$ of men smoked ('PolMonica', Warsaw 1984), in the 1990s there was a decreasing trend in smoking incidence observed among males - 51.9\%), while women remained at the same level - 34.6\% ('PolMonica', Warsaw 1993). After 2000, the number of smokers decreased significantly to about $25 \%$ among women and $40 \%$ among men ('NATPOL PLUS' 2002, 'WOBASZ' 2003-2005) [27]. In the 'Ryzyko' programme the average percentage of smokers among Internet users (18-99 years age group) was $30.8 \%$ (males - 32.7\%; females - 28.6\%), which was lower than in the cited studies. However, there was a clear downward trend in cigarette smoking prevalence, a likely result considering the time of gathering the information in the 'Ryzyko' programme. The most recent data is from 2012.

An interesting observation is the analysis of risk factors in the group of Internet users declaring diabetes. The prevalence of diabetes in Poland according to the literature data is about $5-7 \%$. In the 'Ryzyko' programme the percentage of Internet users in the general population with diabetes was $7.0 \%$, and increased with age $(2.8 \%$ in the $18-39$ age group; $7.9 \%$ in the $40-65$ age group; $23.8 \%$ in the $66-99$ age group). This trend, but more pronounced, can also be seen in the group of Internet users declaring coronary artery disease. The percentage of Internet users with coronary artery disease in age group $18-39$ years was 3.9\%, in the age group 40-65 years $-16.3 \%$ (females) and $47.4 \%$ (males) in the $66-99$ age group, and $13.8 \%$ in the general population (males $-16.7 \%$; females $-10.2 \%$ ). It is an interesting fact that Internet users in the subpopulation with diabetes and coronary artery disease, had higher absolute values of risk factors (TC, SBP), and the percentage declaring cigarette smoking was also higher than in the general population. The obtained data show that in the group with diabetes the parameters were even higher than in the group with coronary artery disease.

The 'Ryzyko' programme as an epidemiological tool, of course, has its limitations resulting from the method of gathering the information. Every Internet user had the possibility to re-enter data into the programme in order to obtain a result of the solved algorithm, and was free to enter the data (within the limits specified in the methods of the work). This allowed the programme to fulfill an educational function, although it can be certain that some of the Internet users input completely false information. On the other hand, thanks to the large number of entries, the extreme values did not have much value in the overall analysis, and due to the large number of gathered data, after analysis the data was comparable with the results obtained from other controlled studies.

To obtain a result of the calculated risk it is necessary, inter alia, to input the total cholesterol concentration and systolic blood pressure values. This is another weak point of the programme because not all Internet users are aware of the value of their medical parameters.

From an educational point of view, is preferable that the total cholesterol concentration and systolic blood pressure required by the programme may lead to the website visitor to consult his/her family doctor in order to determine the concentration of total blood cholesterol, and perform blood pressure measurement. The most effective form of therapy 
appears to be the adequate motivation of the patient to adhere to medical recommendations, such as taking prescribed drugs regularly, or leading a healthy life style. The motivation depends on the patient's knowledge about the disease, prevention of diseases and their consequences.

Thanks to automatic computer IP and codes of residence gathering during every entry on the website, it is possible to observe an epidemiological map of CV risk factors in Poland. Analysis of the multiple entries on the website has been performed, and showed that there were 11 computer IPs that have been connecting to the 'Ryzyko' programme multiple times $(>100)$. It can therefore be assumed that the programme was used as a diagnostic and decision-making tool in medical facilities.

It seems that the ease of monitoring the values input and calculated with the presented programme can have a significant impact on improving the adherence to medical recommendations.

\section{Funding Statement}

The study was supported by funds of the Polish National Science Centre granted to JS on the basis of the decision no. DEC-2012/07/B/NZ5/00017. The funders had no role in the study design, data collection and analysis, decision to publish, or preparation of the manuscript.

\section{REFERENCES}

1. World Health Organization Regional Office for Europe, Copenhagen, 2010. European Health for All database (HFA-DB). http://euro.who. int/hfadb.

2. World Health Organization. International Statistical Classification of Diseases and Related Health Problems. 10th Revision. Version for 2007. http://apps.who.int/classifications/apps/icd/icd10online/.

3. Główny Urząd Statystyczny (Central Statistical Office). Mały Rocznik Statystyczny Polski 2010. Zakład Wydawnictw Statystycznych, Warszawa 2010.

4. Eurostat, The Statistical Office of the European Union. Eurostat. Updated 2009. http://epp.eurostat.ec.europa.eu/tgm/table.do?tab=ta ble\&init $=1$ \&plugin $=1$ \&language $=$ en $\&$ pcode $=$ tps00119

5. European guidelines on cardiovascular disease prevention in clinical practice. Fourth Joint Task Force of the European Society of Cardiology and Other Societies on Cardiovascular Disease Prevention in Clinical Practice (Continued by representatives of nine societies and by invited experts). Eur J Cardiov Prev R. 2007; 4 (Suppl 2).

6. Yusuf S, Hawken S, Ounpuu S, Dans T, Avezun A, Lanas F, et al Effect of potentially modifiable risk factors associated with myocardial infarction in 53 countries (the INTERHEART study): case-control study. Lancet. 2004; 11; 364(9438): 937-52.

7. Virtanen M, Ferrie JE, Singh-Manoux A, Shipley MJ, Vahtera J, Marmot MG, et al. Overtime work and incident coronary heart disease: the Whitehall II prospective cohort study. Eur Heart J. 2010; 31: 1737-44. Date of Electronic Publication: 2010 May 11.

8. Conroy RM, Pyorala K, Fitzerald AP, Sans S, Menotti A, De Backer $\mathrm{G}$, et al. Estimation of ten-year risk of fatal cardiovascular disease in Europe: the SCORE project. Eur Heart J. 2003; 24:987-1003.

9. Mancia G, De Backer G, Dominiczak A, Cifkova R, Fagard R, Germano G, et al. 2007 ESH-ESC practice Guidelines for the Management of Arterial Hypertension. ESH-ESC Task Force on the Management of Arterial Hypertension. J Hypertens. 2007; 25: 1751-1762.

10. Answer of Secretary of State in the Ministry of Infrastructure - the interpellation No. 2321 on access to the Internet in Poland. http://orka2. sejm.gov.pl/IZ6.nsf/main/5DCB6BC1.
11. Feldman RD, Campbell N, Larochelle P, Bolli P, Burgess ED, Carruthers SG, et al. 1999 Canadian recommendations for the management of hypertension. CMAJ. 1999; 161(Suppl 12): S1-S17.

12. Campbell NR, McAlister FA, Brant R, Levine M, Drouin D, Feldman $\mathrm{R}$, et al. Canadian Hypertension Education Process and Evaluation Committee Temporal trends in antihypertensive drug prescriptions in Canada before and after introduction of the Canadian Hypertension Education Program. J Hypertens. 2003; 21(8): 1591-1597.

13. Quinn RR, Hemmelgarn BR, Padwal RS, Myers MG, Cloutier L, Bolli P, et al. Canadian Hypertension Education Program. The 2010 Canadian Hypertension Education Program recommendations for the management of hypertension: part I - blood pressure measurement, diagnosis and assessment of risk. Can J Cardiol. 2010; 26(5): 241-248.

14. Hackam DG, Khan NA, Hemmelgarn BR, Rabkin SW, Touyz RM, Campbell NR, et al. Canadian Hypertension Education Program. The 2010 Canadian Hypertension Education Program recommendations for the management of hypertension: part 2 - therapy. Can J Cardiol. 2010; 26(5): 249-258.

15. AHA/ACCF 2009 Performance Measures for Primary Prevention of Cardiovascular Disease in Adults. A Report of the American College of Cardiology Foundation/American Heart Association Task Force on Performance Measures (Writing Committee to Develop Performance Measures for Primary Prevention of Cardiovascular Disease): Developed in Collaboration With the American Academy of Family Physicians; American Association of Cardiovascular and Pulmonary Rehabilitation; and Preventive Cardiovascular Nurses Association. Circulation. 2009; 120: 1296-1336.

16. Babińska Z, Bandosz P, Nowicka-Sauer K, Trzeciak B, Pietrzykowska M, Gutknecht P, Siebert J. The cognizance of patient s own blood pressure values and the hypertension prevalence among rural population „Kiełpino program”. Family Med Prim Care Rev. 2007; 9(3): 363-365.

17. Raport CBOS - korzystanie z Internetu. Warszawa, lipiec 2009 BS/96/2009. www.cbos.pl.

18. The percentage of women and men use the Internet regularly by regular use of the Internet among men and women (EU countries). http://www. internetstats.pl 1.10.2010

19. Jóźwiak J, Mastej M, Lukas W, Kądziołka M, Orzechowski M. Lipidogram 2003 - evaluation and comparison of lipidogram parameters and body mass index in relation with patients' gender and age in population of South and West Poland. Part 1.: evaluation of body mass index (BMI) in relation with sex and age. Probl Med Rodz. 2005; 7: 27-32.

20. Mastej M, Jóźwiak J, Lukas W, Piwowarska W, Tykarski A, Orzechowski M. Evaluation and comparison of lipid parameters, depending on gender and body mass index (BMI). Kariol Pol. 2006; 64, 8 (Suppl 2): S153-S160.

21. Tendera M, Kozakiewicz K, Bartnik M, et al. The presence of major risk factors of coronary heart disease in a group of 41927 people under the action of primary prevention in southern Poland (Poland Epidemiological Survey Southeren - SPES). Wiad Lek. 2001; 5: 293-303.

22. Pająk A, Wiercińska E, Polakowska M, Kozakiewicz K, KaczmarczykChałas K, Tykarski A, et al. Rozpowszechnienie dyslipidemii u mężczyzn i kobiet w wieku 20-74 lat w Polsce. Wyniki programu WOBASZ. Kardiol Pol. 2005; 63 : 6 (Suppl 4): 2-6.

23. Zdrojewski T, Bandosz P, Szpakowski P, Konarski R, Jakubowski $\mathrm{Z}$, Manikowski A, et al. The prevalence of major risk factors of the cardiovascular diseases in Poland. The results of NATPOL PLUS Study. Kardiol Pol. 2004; 61 (Suppl IV): 1-26.

24. Rywik S, Broda G, Piotrowski W, et al. Epidemiologia chorób układu krążenia. Program Pol-MONICA Warszawa. Kardiol Pol. 1996; 44 (Supl. II).

25. Pająk A, Kawalec E. Rozpowszechnienie i skuteczność postępowania w nadciśnieniu tętniczym. Wyniki badania długofalowego Pol-MONICA Kraków. Medipress Kardiologia. 1994; 1: 3-6.

26. Kawecka-Jaszcz K, Pościk-Urbańska A, Jankowski P. Rozpowszechnienie nadciśnienia tętniczego w zależności od płci w świetle badań epidemiologicznych w Polsce. Nadciśn Tętn. 2007; 11: 377-383.

27. Podolec P, Kopeć G. Rozpoznawanie palenia tytoniu wśród dorosłych Polaków - wyniki badania POLSCREEN. W: Cieśliński A, Pająk A, Podolec P, Rynkiewicz A. Ogólnopolski Program Prewencji Choroby Wieńcowej POLSCREEN. Termedia. Poznań, 2006. Wyd I. p. 69-81. 